\title{
Relationship between Selected Soil Physico-Chemical Characteristics and Mycorrhizal Status under Triumfetta cordifolia in the Cameroon Western Highlands
}

\author{
Romary Tchinda Ngnipa ${ }^{*}$, Fritz Oben Tabi1, Souleymanou Adamou2 ${ }^{2}$, Primus Azinwi Tamfuh ${ }^{1,3}$, \\ Georges Kogge Kome ${ }^{1}$, Alexis Boukong ${ }^{1}$, Antoine David Mvondo Ze ${ }^{1}$
}

\footnotetext{
${ }^{1}$ Department of Soil Science, Faculty of Agronomy and Agricultural Sciences, University of Dschang, Dschang, Cameroon ${ }^{2}$ Department of Agriculture, Faculty of Agronomy and Agricultural Sciences, University of Dschang, Dschang, Cameroon ${ }^{3}$ Department of Mining and Mineral Engineering, National Higher Polytechnic Institute, University of Bamenda, Bambili, Cameroon
}

Email: *ngniparomary@gmail.com

How to cite this paper: Ngnipa, R.T., Tabi, F.O., Adamou, S., Azinwi Tamfuh, P., Kome, G.K., Boukong, A. and Mvondo Ze, A.D. (2021) Relationship between Selected Soil Physico-Chemical Characteristics and Mycorrhizal Status under Triumfetta cordifolia in the Cameroon Western Highlands. Open Journal of Soil Science, 11, 216-240.

https://doi.org/10.4236/ojss.2021.114012

Received: December 5, 2020

Accepted: February 22, 2021

Published: April 25, 2021

Copyright ( 2021 by author(s) and Scientific Research Publishing Inc. This work is licensed under the Creative Commons Attribution International License (CC BY 4.0).

http://creativecommons.org/licenses/by/4.0/ (c) (i) Open Access

\section{Abstract}

There is limited information on the pedological requirements of Triumfetta cordifolia. A starting point for establishing such information requires knowledge on the growing environment of the species. The aim of this study was to assess the physicochemical properties and mycorrhizal status in the rhizosphere of Triumeffa cordifolia. Soil and root samples from the rhizosphere of $T$. cordifolia were collected from three localities (Santchou, Bandjoun, and Balatchi) in the West Region of Cameroon. The results show that the soils are dominated by a loamy texture and have a mean porosity $>50 \%$. Mean bulk density ranges from $0.91 \pm 0.02$ to $1.26 \pm 0.04 \mathrm{~g} \cdot \mathrm{cm}^{-3}$. The sum of exchangeable cations ranges from medium $(6.45 \pm 1.02)$ to high $(11.21 \pm 1.35)$ and are evident of the satisfactory soil organic matter $(\mathrm{OM})$ content in the various localities $(5.90 \% \pm 0.42 \%$ to $10.65 \% \pm 0.73 \%)$. Total nitrogen (TN) content of the soils ranged from low $(0.10 \%)$ to very high $(0.41 \%)$. Biological activity is low due to very poor OM quality (mean $\mathrm{C} / \mathrm{N}>20$ ). The average available phosphorus status ranged from medium $(18.32 \pm 3.91 \mathrm{ppm})$ to very high $(69.39 \pm 26.09 \mathrm{ppm})$. The Cationic Exchange Capacity (CEC) was moderate $\left(19.28-29.28 \mathrm{cmol} \cdot \mathrm{kg}^{-1}\right)$ and was mainly contributed by soil organic matter. Base saturation ranged from low (28.0\%) to medium (48.83\%). Assessment of endomycorrhizal colonization showed that the intensity (I), frequency ( $\mathrm{Fr}$ ) and specific density of spores (Ds) were not significantly different among 
sites. A high level of available $\mathrm{P}$ in the Santchou soils appears to be the major cause for the lowest values of Fr, I, and Ds observed. These results reaffirm the link between soil physicochemical properties and endomycorrhizal infection in T. cordifolia. Site characteristics and soil OM quality are factors to be considered in promoting the establishment of mycorrhizal symbiosis for profitable and sustainable cultivation of $T$. cordifolia.

\section{Keywords}

Triumfetta cordifolia, Soil Properties, Arbuscular Mycorrhizal Fungi, Sustainable Soil Management, Western Cameroon Highlands

\section{Introduction}

With an average food deficit of malnourished people of $>300$ kilocalories per day, sub-Saharan Africa has the most undernourished population in the world [1]. Paradoxically, African countries are endowed with important agricultural biodiversity such as indigenous African vegetables [2], which could significantly contribute to the fight against this scourge [3]. As opposed to exotic vegetables, they generally show a higher value in terms of vitamins and nutritional salts [4] and do not require high inputs of pesticides or mineral fertilizers for their production, thus reducing the risk of environmental pollution [5]. T. cordifiolia is an indigenous African vegetable spread throughout the tropics and frequently encountered in Cameroon [6] [7] [8] where it is commonly consumed in the form of a mucilaginous sauce called Nkui in the West Region of Cameroon [9]. In the North region of Cameroon, the incorporation of $T$. cordifolia gums into sorghum and corn flours significantly improves the swelling of the paste and the physical and organoleptic characteristics of the dough, thus substituting chemical yeasts [10]. The fiber of this plant has been used to make textile, cloth, bags, packaging material mats, and baskets [11]. Recent studies have shown that $T$. cordifolia is widely used in African traditional medicine and can be considered a potential source of useful drugs [12]. In Africa, it is used for the treatment of various diseases such as gastrointestinal disorders, diarrhea ulcers [13], dyspnea, intercostals neuralgia and benorrhoea [14], venereal diseases, liver, kidney disorders and delayed labor [15]. The plant is also known to be psychotropic [16], used for hair care [17], eases childbirth and fights sterility in women, induces weight loss, and is said to have anti-hyperlipemic properties [18]. The decoction of the flowers is used for the treatment of malaria and to fight against nausea [12]. Many active biomolecules have been isolated from the leaves, stems, and roots of $T$. cordifolia such as alkaloids, saponins, tannins, steroids, terpenes, cardiac glycosides, and flavonoids like quercetin [16], ceramides [19], and some acids such as etulinic acid, maslinic acid, stigmasterol, tormentic acid, heptadecanoic acid, oleanolic acid and lupeol [15] [20] [21]. This is indicative of its 
diverse biological activities including antidiabetic, antibacterial, antifungal, antidiarrhoeal, antiulcerogenic, antimicrobial, analgesic, cytotoxic and anti-inflammatory [13] [16] [21]. Additionally, the maslinic acid and its oxidized derivative, betulinic acid is known to have anti-HIV activity [15] [22].

Despite its multiple nutritional and medicinal values, the species is either vulnerable or endangered due to overexploitation and destruction of its natural habitat by population growth associated with the absence of relevant policies for restoration strategies and conservation. In the Western Highlands of Cameroon, this loss of biodiversity is mainly aggravated by the acidification and nutrient depletion in soils [23]. Thus, there is an urgent need to protect the species both in situ in its natural environment or promote its cultivation as a cash crop. These actions require prior knowledge of the characteristics of the site and the edaphic and microbiological requirements of the species in order to guarantee the success and sustainability of restoration and conservation strategies. Numerous studies have shown that Arbuscular Mycorrhizal Fungi (AMF) improve water and mineral nutrition in plants, particularly the absorption of phosphorus [24] [25]. In India [26] [27] [28] and in Australia [29] colonization rates of AMF on T. rhomboidei varied respectively from $94 \%, 19 \%, 30 \%$ and $25 \%-50 \%$. However, no study has yet been carried out in Cameroon on infection with AMF associated with $T$. cordifolia. The objective of this study was to assess the physicochemical properties and mycorrhizal status in the rhizosphere of $T$. cordifolia in the Western Highlands of Cameroon. The information generated will be a baseline contribution to the knowledge and sustainable management of T. cordifolia in this area and beyond.

\section{Materials and Methods}

\subsection{Biophysical Description of the Study Area}

This study was carried out in the localities of Santchou, Bandjoun and Balatchi in the West Region of Cameroon (Figure 1). These localities are areas with high consumption of $T$. cordifolia. Santchou (N $5^{\circ} 10^{\prime}$, E 10 20', altitude: $719 \mathrm{~m}$ ), Bandjoun ( $5^{\circ} 22^{\prime}$, E $10^{\circ} 24^{\prime}$, altitude: $1520 \mathrm{~m}$ ), Balatchi (N 5 $37^{\prime}, \mathrm{E} 10^{\circ} 10^{\prime}$, altitude: $1849 \mathrm{~m}$ ) are characterized by a two-season bimodal rainfall pattern, a rainy season from March to November and a dry season from December to February. Precipitation and annual temperatures are respectively $2429 \mathrm{~mm}$ and $24^{\circ} \mathrm{C}$ in Santchou [30], $1517 \mathrm{~mm}$ and $20^{\circ} \mathrm{C}$ in Bandjoun [31], $1764 \mathrm{~mm}$ and $23^{\circ} \mathrm{C}$ in Balatchi [32]. Hydromorphism characterizes the main pedogenetic process in Santchou, more particularly in lowlands [33]. Bandjoun is characterized by generally ferrallitic soils (Ferrasols) on acidic rocks and on basic rocks [34] while the Balatchi soils are classified as Humic Rhodic Ferralsol (Dystric, Clayic) [35]. The different localities are characterized by vegetation composed mainly of food crops (maize, plantain, beans, yams, etc.) and species such as Rafia vinifera, Eucalyptus grandis, Imperata cylindrica and Pennisetum purpureum, Albizia gummifera and Triumfetta cordifolia. 


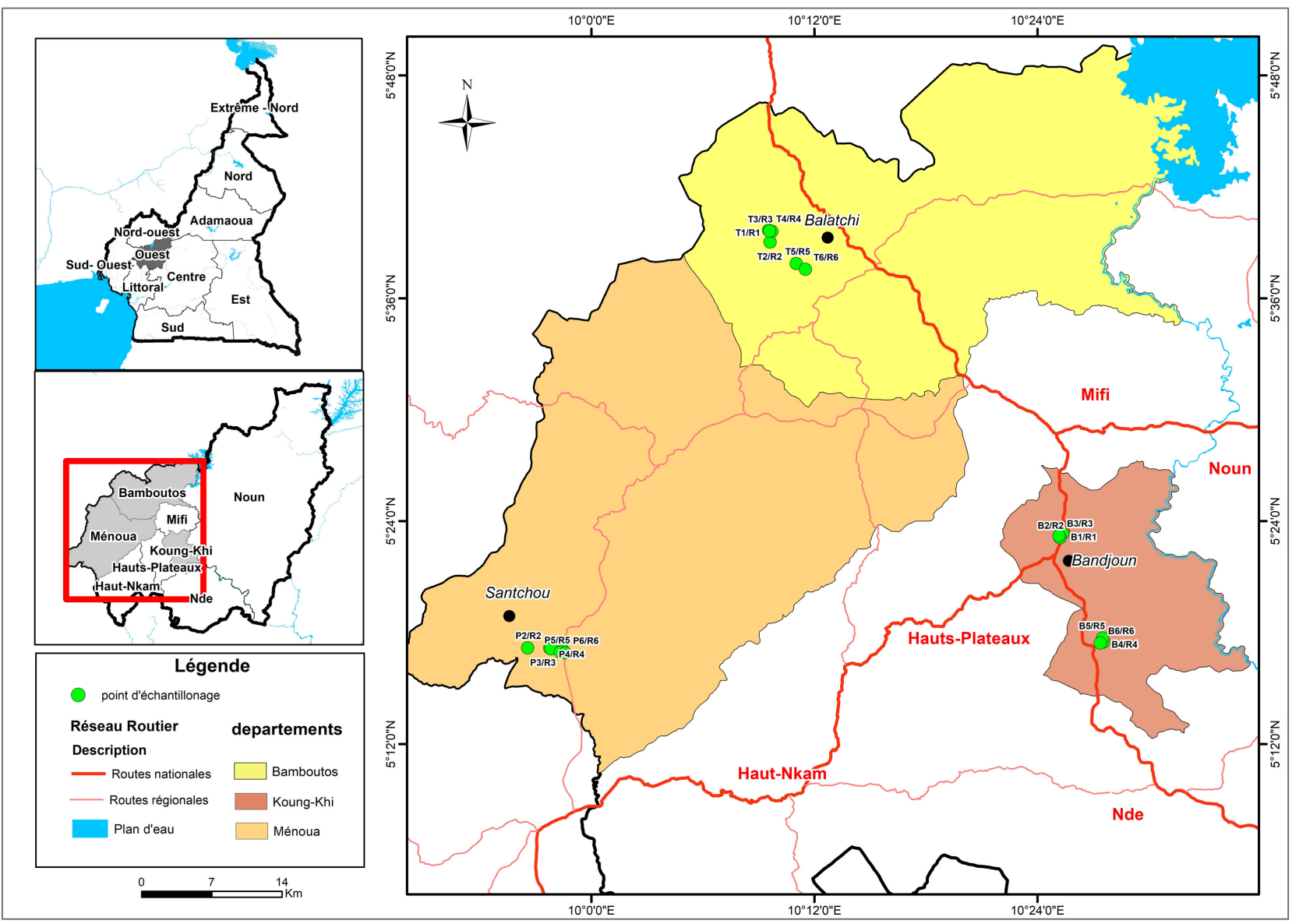

Figure 1. Sampling sites for soil and roots of Triumfetta cordifolia in the study area.

\subsection{Soil and Root Sampling}

In each of the three localities six plots of $T$. cordifolia were randomly selected. On each of these plots, a composite sample of $500 \mathrm{~g}$ of the topsoil $(0-20 \mathrm{~cm}$ depth) was collected using a manual auger at three different points at the base of 3 to 5 plants of $T$. cordifolia and stored in plastic bags. In addition, $50 \mathrm{~g}$ of a composite sample of fine roots of $T$. cordifolia from each of the plots was taken with a knife. GPS coordinates of each sample were recorded. The samples were transported to the Soil Analysis and Environmental Chemistry Laboratory (LABASCE) of the University of Dschang (Cameroon). Part of the soil samples was dried in ambient air for $72 \mathrm{~h}$ and stored in the refrigerator at $4^{\circ} \mathrm{C}$ for subsequent inoculation while another part was dried in the open air, crushed and sieved using a $2 \mathrm{~mm}$ sieve for physico-chemical analyses. The root samples were washed with tap water, rinsed with distilled water and then placed in sterilized jars containing alcohol at $70^{\circ} \mathrm{C}$. These jars were then stored in the refrigerator at $4^{\circ} \mathrm{C}$.

\subsection{Physico-Chemical Analysis of Soils}

Physical and chemical properties were determined according to standard procedures described by Pauwels et al. [36]. The particle size distribution was 
measured by the Robinson's pipette method. Bulk density (Da) was measured by the paraffin coating method. Soil porosity (Po) was calculated from bulk density (Da) and particle density (Dp) using the formula in Equation (1):

$$
\mathrm{Po}=\left(1-\frac{\mathrm{Da}}{\mathrm{Dp}}\right) \times 100
$$

where, $\mathrm{Da}=$ bulk density and $\mathrm{Dp}=$ particle density $\left(2.65 \mathrm{~g} / \mathrm{cm}^{3}\right)$.

Soil $\mathrm{pH}-\mathrm{H}_{2} \mathrm{O}$ and $\mathrm{pH}-\mathrm{KCl}$ were respectively determined in a soil/water ratio of $1: 2.5$ and a soil/ $\mathrm{KCl}$ solution of 1:2.5 and values were read with a $\mathrm{pH}$-meter. Organic carbon (OC) was measured by the Walkley-Black method. Total nitrogen (TN) and available phosphorus were determined by Kjeldahl and Bray II to wet digestion methods, respectively. Exchangeable cations $\left(\mathrm{Na}^{+}, \mathrm{K}^{+}, \mathrm{Ca}^{2+}, \mathrm{Mg}^{2+}\right)$ were determined according to the Schollenberger method by leaching $2.5 \mathrm{~g}$ of soil with $100 \mathrm{ml}$ of a $1 \mathrm{M}$ ammonium acetate solution buffered at $\mathrm{pH}$. The concentrations of $\mathrm{Na}^{+}$and $\mathrm{K}^{+}$ions in the extract were obtained by flame photometry and those of $\mathrm{Ca}^{2+}$ and $\mathrm{Mg}^{2+}$ were estimated by complexometric titration using a $0.002 \mathrm{M} \mathrm{Na}_{2}$-EDTA solution. Cation exchange capacity (CEC) was estimated by leaching $2.5 \mathrm{~g}$ of soil with $100 \mathrm{ml}$ of a $1 \mathrm{M}$ ammonium acetate solution buffered at $\mathrm{pH}$ 7. A $1 \mathrm{~N} \mathrm{KCl}$ solution was used to displace $\mathrm{NH}_{4}^{+}$ions from the soil complex, and the displaced ions were determined by distillation and titration with $0.01 \mathrm{~N} \mathrm{H}_{2} \mathrm{SO}_{4}$.

The Fertility Index (IF) was calculated using the equation proposed by [37].

$$
\mathrm{IF}=\mathrm{P}+\mathrm{Da}+\mathrm{CEC}+\mathrm{pH}-\mathrm{H}_{2} \mathrm{O}+\mathrm{OM}+\mathrm{NT}+\mathrm{Po}+\Delta \mathrm{pH}+\mathrm{SCE}
$$

where, $\mathrm{P}=$ Available phosphorus, $\mathrm{Da}=$ Bulk density, $\mathrm{CEC}=$ Cation Exchange Capacity, $\mathrm{OM}=$ Organic matter content, NT: Total nitrogen, Po = porosity, $\Delta \mathrm{pH}=\mathrm{pH}-\mathrm{KCl}-\mathrm{pH}-\mathrm{H}_{2} \mathrm{O}, \mathrm{SCE}=$ Sum of exchangeable cations. Soil requirements in basic cations were calculated using the nutrient deficiency method [38].

\subsection{Root Colonization Parameters}

The fine roots ( 1 to $2 \mathrm{~cm}$ ) were thinned following the method of Phillips and Hayman [39] and stained based on Vierheilig et al. [40]. They were washed thoroughly with distilled water, put in a test tube with $10 \% \mathrm{NaOH}$ and heated in a water bath at $90^{\circ} \mathrm{C}$ for 30 minutes with the aim to empty the contents of the cytoplasm and to facilitate the observation of the structures. The sodium hydroxide was then discarded, filtered through a sieve, before neutralization by rinsing with acidified water. The neutralized roots were immersed in beakers containing $10 \mathrm{ml}$ of a solution composed of $95 \%$ white vinegar and $5 \%$ blue ink and placed in a water bath for 3 minutes at $95^{\circ} \mathrm{C}$ [40]. They were then sieved and rinsed using tap water acidified with a few drops of vinegar. The discoloration was obtained by introducing a solution composed of acetic acid, water and glycerol in the ratio of 2:1:1. The discoloured roots were stored in $50 \%$ glycerol for later observation [41]. Ten root fragments were mounted on a glass slide. The experiment was repeated three times for each sample. The observation was made under a light microscope (Leica LCC $50 \mathrm{HD}, 40 \times$ ). For each fragment, the fre- 
quency (Fr) and the intensity (I) of the mycorrhization were evaluated by the method of [42].

\subsection{Trapping of Arbuscular Mycorrhizal Fungi}

AMF spore trapping was done in a greenhouse. The local variety of cowpea (Vinia unguiculata) and common millet (Panicum miliaceum) were used as the reference trap plant. For each plot, three polyethylene bags $(15 \times 28 \mathrm{~cm}, 250 \mu \mathrm{m}$ thick) were used with one repetition each [43]. Each sachet was composed of 2.2 $\mathrm{kg}$ of substrate composed of a mixture of $2 \mathrm{~kg}$ of sterilized substrate and $200 \mathrm{~g}$ of inoculum. In each sachet, $1.8 \mathrm{~kg}$ of the sterilized substrate was introduced and three rows of seedlings were first covered with $200 \mathrm{~g}$ of soil inoculum evenly distributed over the three rows above the sterilized substrate. Subsequently, three seeds from each trap plant, previously sterilized in alcohol at $90^{\circ} \mathrm{C}$ for one minute and rinsed with distilled water, were bagged along the three lines of the inoculum. Each sachet was then covered with $200 \mathrm{~g}$ of remaining sterilized substrate. The trap cultures were kept in the shelter for a period of 6 months for the germination of the spores. The sprouted plants were watered daily throughout the development phase. A re-sowing was carried out each time a plant reached senescence.

\subsection{Extraction of Spores and Evaluation of the Specific Density}

AMF spores were isolated from $100 \mathrm{~g}$ of soil taken from each sachet. The spores were extracted by wet sieving through a series of nested sieves $(150,75,45,38$ $\mu \mathrm{m})$ according to Gerdemann and Nicolson [44]. Soil particles retained in the last two sieves ( 45 and $38 \mu \mathrm{m}$ ) were transferred into a beaker. By successive sampling, small quantities of the solution in the beaker were introduced into kneaders. The abundance of spores was estimated by direct observation with a binocular magnifying glass. The specific density of the spores was calculated according to the formula proposed by Sghir et al. [45]. It indicates the spores contained in $100 \mathrm{~g}$ and is expressed from Equation (3):

$$
\mathrm{D}(\%)=\mathrm{N} / 100 \mathrm{~g}
$$

where: $\mathrm{N}=$ number of spores.

\subsection{Statistical Analysis}

Excel 2016 software was used for data processing. SPSS 23 software was used for descriptive analyses of soil physicochemical properties. The Student-Newman-Keuls test was used to compare the means at the $5 \%$ threshold. Data not conforming to ANOVA assumptions (normality and homogeneity of variance tested by the Shapiro-Wilk test, respectively) were subjected to the Kruskal Wallis test.

\section{Results and Discussion}

\subsection{Soil Physicochemical Characteristics}

Descriptive statistics and coefficient of variation (CV) of soil physicochemical 
properties and their mycorrhizal parameters are shown in Table 1 while descriptive statistics of nutrient ratios and fertility index are shown in Table 2. The results of particle size analysis of the Santchou, Bandjoun, and Balatchi soils showed that the sandy and silty fractions dominated the clay fraction with $\mathrm{cu}$ mulative values of $77.50 \%, 85.82 \%, 88.66 \%$ respectively for the Santchou, Bandjoun and Balatchi soils, thus giving the soils a loamy texture. Particle size distribution has an important influence on soil water movement, aeration, root extension, nutrient and OM contents as well as chemical composition [46]. Soils with a loamy texture contain enough sand to drain water, but enough clay and silt to retain the moisture needed by many plants. These results show that the soils of the study area are suitable for most crops including those of malvaceae such as Okra (Abelmoschus esculentus L.) and cotton (Gossypium) [37] [47].

The mean bulk densities $(\mathrm{Da})$ of the three sites are respectively $1.26 \pm 0.04$ $\mathrm{g} / \mathrm{cm}^{3}$ (Santchou), $1.05 \pm 0.02 \mathrm{~g} / \mathrm{cm}^{3}$ (Bandjoun) and $0.91 \pm 0.02 \mathrm{~g} / \mathrm{cm}^{3}$ (Balatchi). The A horizons of cultivated soils normally have a bulk density ranging from 0.9 to $1.8 \mathrm{~g} / \mathrm{cm}^{3}$, with values below this range characterizing organic layers or volcanic ash [48] meanwhile clay soils with a $\mathrm{Da}>1.55 \mathrm{~g} / \mathrm{cm}^{3}$ are unfavourable to root penetration due to their compactness [49]. The normal range of bulk densities for clay soils is between 1.0 and $1.6 \mathrm{~g} / \mathrm{cm}^{3}$ with potential root restriction for $\mathrm{Da} \geq 1.4 \mathrm{~g} / \mathrm{cm}^{3}$ [50] [51]. Thus the bulk densities of the studied soils are favourable for root development.

The porosity (Po) of soils varies respectively by $50.17 \% \pm 1.25 \%$ (Santchou), $58.83 \% \pm 0.83 \%$ (Bandjoun) and $62.83 \% \pm 0.79 \%$ (Balatchi). The soil fertility is better when there is no excessive variation in its porosity as a function of humidity [52]. Total porosity of less than $30 \%$ is considered to be poor, the best being greater than 50\% [53] and according to Yerima and Van Ranst [49], soils associated with low porosity and fine texture seriously hinder the growth of plants, due to their more or less asphyxiating character. The soils in this study thus have good porosity.

This could be linked to high organic matter contents, fine textures $(<2 \mu \mathrm{m})$ and also to the rhizosphere effect which, coupled with the strong activity of the microfauna, has contributed to increasing the voids between the aggregates, thereby lowering bulk density [54].

The soil $\mathrm{pH}$ values indicate that the Santchou and Bandjoun soils have a slightly acidic $\mathrm{pH}-\mathrm{H}_{2} \mathrm{O}$ while those of Balatchi are moderately acidic [38]. Soil $\mathrm{pH}$ is a determining property of the availability of nutrients for plants and soil microorganisms [55] [56]. Overall, $\mathrm{pH}-\mathrm{KCl}$ is slightly lower than $\mathrm{pH}-\mathrm{H}_{2} \mathrm{O}$ indicating that the net charge balance on the adsorbent complex was negative, and therefore exhibited cation exchange capacity (CEC). This characteristic is a favourable element for the cultivation of Malvaceae [37].

The CEC is moderate for all the soils studied [38]. This indicator represents the capacity of the solid phase of the soil to retain and release certain cations, in particular those directly involved in plant nutrition [57]. The CEC, which is in fact a functional property of soil, illustrates both its function as a reservoir for 
Table 1. Descriptive statistics and coefficient of variation of physicochemical and mycorrhizal properties $(n=6)$.

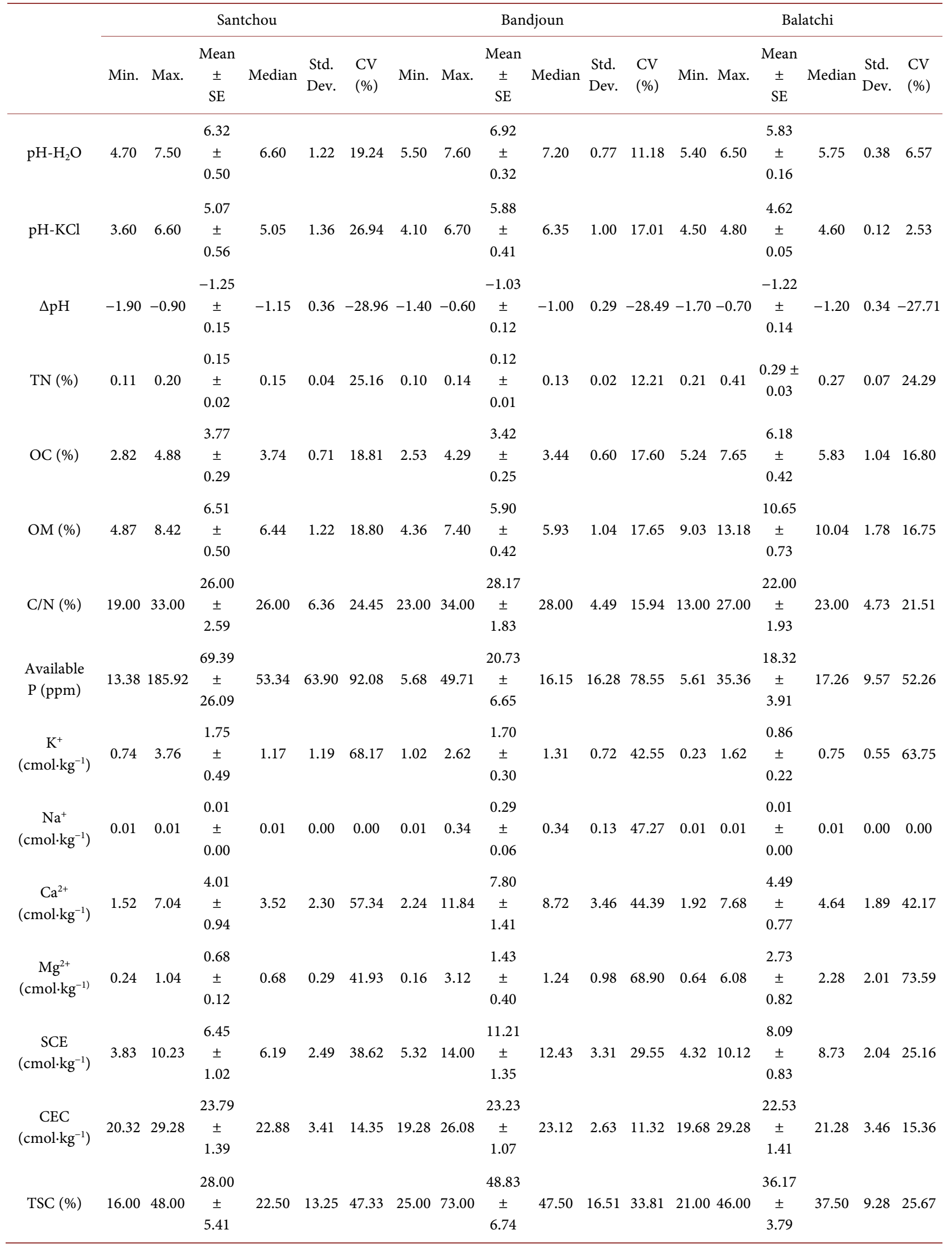




\section{Continued}

\begin{tabular}{|c|c|c|c|c|c|c|c|c|c|c|c|c|c|c|c|c|c|c|}
\hline & & & 22.50 & & & & & & 14.17 & & & & & & 11.33 & & & \\
\hline Clay (\%) & 16.00 & 32.00 & $\begin{array}{c} \pm \\
2.66\end{array}$ & 21.50 & 6.50 & 28.91 & 9.00 & 21.00 & $\begin{array}{c} \pm \\
1.72\end{array}$ & 14.00 & 4.22 & 29.75 & 10.00 & 13.00 & $\begin{array}{c} \pm \\
0.49\end{array}$ & 11.50 & 1.21 & 10.69 \\
\hline Silt (\%) & 27.00 & 45.00 & $\begin{array}{c}32.00 \\
\pm \\
2.68\end{array}$ & 29.50 & 6.57 & 20.54 & 31.00 & 42.00 & $\begin{array}{c}34.83 \\
\pm \\
2.02\end{array}$ & 32.50 & 4.96 & 14.23 & 36.00 & 46.00 & $\begin{array}{c}41.33 \\
\pm \\
1.50\end{array}$ & 41.50 & 3.67 & 8.88 \\
\hline Sand (\%) & 36.00 & 55.00 & $\begin{array}{c}45.50 \\
\pm \\
2.88\end{array}$ & 46.50 & 7.06 & 15.53 & 45.00 & 60.00 & $\begin{array}{c}51.00 \\
\pm \\
2.32\end{array}$ & 50.00 & 5.69 & 11.16 & 42.00 & 53.00 & $\begin{array}{c}47.33 \\
\pm \\
1.76\end{array}$ & 47.50 & 4.32 & 9.13 \\
\hline $\mathrm{Da}\left(\mathrm{g} / \mathrm{cm}^{3}\right)$ & 1.10 & 1.33 & $\begin{array}{c}1.26 \\
\pm \\
0.04\end{array}$ & 1.28 & 0.09 & 6.86 & 1.00 & 1.11 & $\begin{array}{c}1.05 \\
\pm \\
0.02\end{array}$ & 1.03 & 0.05 & 4.47 & 0.84 & 0.96 & $\begin{array}{c}0.91 \\
\pm \\
0.02\end{array}$ & 0.92 & 0.05 & 5.30 \\
\hline Po (\%) & 48.00 & 56.00 & $\begin{array}{c}50.17 \\
\pm \\
1.25\end{array}$ & 49.00 & 3.06 & 6.10 & 56.00 & 61.00 & $\begin{array}{c}58.83 \\
\pm \\
0.83\end{array}$ & 59.00 & 2.04 & 3.47 & 61.00 & 66.00 & $\begin{array}{c}62.83 \\
\pm \\
0.79\end{array}$ & 62.50 & 1.94 & 3.09 \\
\hline $\operatorname{Fr}(\%)$ & 23.33 & 60.00 & $\begin{array}{c}42.22 \\
\pm \\
5.28\end{array}$ & 40.00 & 12.94 & 30.64 & 23.33 & 90.00 & $\begin{array}{c}51.67 \\
\pm \\
9.06\end{array}$ & 50.00 & 22.19 & 42.94 & 33.33 & 80.00 & $\begin{array}{c}59.44 \\
\pm \\
7.47\end{array}$ & 61.67 & 18.31 & 30.80 \\
\hline I (\%) & 0.80 & 4.03 & $\begin{array}{c}2.16 \\
\pm \\
0.51\end{array}$ & 2.30 & 1.24 & 57.50 & 1.60 & 15.47 & $\begin{array}{c}5.81 \\
\pm \\
2.06\end{array}$ & 4.32 & 5.04 & 86.72 & 1.10 & 7.13 & $\begin{array}{c}3.66 \\
\pm \\
1.11\end{array}$ & 2.93 & 2.71 & 74.04 \\
\hline Ds (\%) & 11.00 & 28.00 & $\begin{array}{c}18.00 \\
\pm \\
2.85\end{array}$ & 16.00 & 6.99 & 38.81 & 22.00 & 40.00 & $\begin{array}{c}30.33 \\
\pm \\
2.76\end{array}$ & 29.50 & 6.77 & 22.33 & 8.00 & 36.00 & $\begin{array}{c}24.17 \\
\pm \\
4.43\end{array}$ & 24.00 & 10.85 & 44.90 \\
\hline
\end{tabular}

Notes: Fr: Frequency of mycorrhization, I: Intensity of mycorrhization, Ds: Specific density of spores, SE: Standard error, CV: Coefficient of variation, Std. Dev.: Standard deviation.

Table 2. Descriptive statistics of nutrient ratios and fertility index $(n=6)$.

\begin{tabular}{|c|c|c|c|c|c|c|c|c|c|c|c|c|c|c|c|c|c|c|}
\hline & \multicolumn{6}{|c|}{ Santchou } & \multicolumn{6}{|c|}{ Bandjoun } & \multicolumn{6}{|c|}{ Balatchi } \\
\hline & Min. & Max. & $\begin{array}{c}\text { Mean } \\
\pm \\
\text { SE }\end{array}$ & Median & $\begin{array}{l}\text { Std. } \\
\text { Dev. }\end{array}$ & $\begin{array}{l}\mathrm{CV} \\
(\%)\end{array}$ & Min. & Max. & $\begin{array}{c}\text { Mean } \\
\pm \\
\text { SE }\end{array}$ & Median & $\begin{array}{l}\text { Std. } \\
\text { Dev. }\end{array}$ & $\begin{array}{l}\mathrm{CV} \\
(\%)\end{array}$ & Min. & Max. & $\begin{array}{c}\text { Mean } \\
\pm \\
\text { SE }\end{array}$ & Median & $\begin{array}{l}\text { Std. } \\
\text { Dev }\end{array}$ & $\begin{array}{l}\text { CV } \\
(\%)\end{array}$ \\
\hline $\begin{array}{c}\mathrm{TN} \\
(\% \mathrm{o}) / \mathrm{pH}-\mathrm{H}_{2} \mathrm{O}\end{array}$ & 0.002 & 0.003 & $\begin{array}{c}0.003 \\
\pm \\
0.000\end{array}$ & 0.003 & 0.001 & 21.909 & 0.002 & 0.002 & $\begin{array}{c}0.002 \\
\pm \\
0.00\end{array}$ & 0.002 & 0.000 & 0.00 & 0.004 & 0.006 & $\begin{array}{c}0.005 \\
\pm \\
0.00\end{array}$ & 0.005 & 0.001 & 17.89 \\
\hline $\mathrm{Mg} / \mathrm{K}$ & 0.18 & 1.08 & $\begin{array}{c}0.55 \\
\pm \\
0.17\end{array}$ & 0.39 & 0.41 & 75.944 & 0.12 & 3.06 & $\begin{array}{c}1.07 \\
\pm \\
0.44\end{array}$ & 0.74 & 1.08 & 101.08 & 0.85 & 8.33 & $\begin{array}{c}4.04 \\
\pm \\
1.18\end{array}$ & 3.89 & 2.90 & 71.81 \\
\hline $\mathrm{Ca} / \mathrm{Mg}$ & 1.73 & 19.33 & $\begin{array}{c}7.77 \\
\pm \\
2.79\end{array}$ & 5.00 & 6.83 & 87.885 & 1.27 & 74.00 & $\begin{array}{c}16.31 \\
\pm \\
11.58\end{array}$ & 6.15 & 28.36 & 173.86 & 0.32 & 6.86 & $\begin{array}{c}2.97 \\
\pm \\
1.05\end{array}$ & 2.04 & 2.57 & 86.59 \\
\hline$(\mathrm{Ca}+\mathrm{Mg}) / \mathrm{K}$ & 0.64 & 7.14 & $\begin{array}{c}3.58 \\
\pm \\
0.88\end{array}$ & 3.32 & 2.15 & 59.960 & 2.50 & 12.40 & $\begin{array}{c}6.53 \\
\pm \\
1.66\end{array}$ & 6.00 & 4.07 & 62.23 & 4.20 & 18.00 & $\begin{array}{c}11.53 \\
\pm \\
2.45\end{array}$ & 11.26 & 6.01 & 52.16 \\
\hline IF & 99.20 & $292.34^{1}$ & $\begin{array}{c}162.82 \\
\pm \\
29.21\end{array}$ & 145.79 & 71.56 & 43.948 & 103.851 & $161.16^{1}$ & $\begin{array}{c}126.80 \\
\pm \\
8.39\end{array}$ & 122.60 & 20.55 & 16.21 & 107.12 & 143.03 & $\begin{array}{c}128.21 \\
\pm \\
5.07\end{array}$ & 130.73 & 12.41 & 9.68 \\
\hline
\end{tabular}

IF: Fertility Index, SE: Standard error, CV: Coefficient of variation, Std. Dev.: Standard deviation. 
plant nutrients and a buffer that dampens the osmotic pressure between the external environment and the root cells. The high CEC values recorded in the soils of this study could be due mainly to the nature of clay minerals and OM to some extent [58]. In the hydromorphic soils of Santchou, the contribution of the clay fraction to soil fertility is greater than that of the organic fraction [59].

Exchangeable cations show that calcium is the most abundant cation in all the soils studied. Nevertheless, its concentration remains low for Santchou and Balatchi but medium for those of Bandjoun [38]. The mean values of magnesium show that it is low for the Santchou and Bandjoun soils, and medium for those of Balatchi. For potassium, the average values show that it is high for the Santchou and Bandjoun soils and very high for those of Balatchi. Sodium is very low (Santchou and Balatchi) to low (Bandjoun). Thus the low $\mathrm{Ca}^{2+}$ and $\mathrm{Mg}^{2+}$ contents recorded in this study are probably due to the high potassium concentration in the soil solution which decreases the absorption of $\mathrm{Ca}^{2+}$ and $\mathrm{Mg}^{2+}$ and its subsequent leaching [60] [61]. In general, the order of magnitude of the exchangeable cations on the adsorbent complex of most tropical soils follows the trend $\mathrm{Ca}^{2+}>\mathrm{Mg}^{2+}>\mathrm{K}^{+}>\mathrm{Na}^{+}$[49] [62]. The Balatchi soils follow this trend unlike the Santchou and Bandjoun soils so the average trend is $\mathrm{Ca}^{2+}>\mathrm{K}^{+}>$ $\mathrm{Mg}^{2+}>\mathrm{Na}^{+}$. This result corroborates that of Nnomo et al. [59] where it was observed that the $\mathrm{Ca}^{2+}>\mathrm{K}^{+}>\mathrm{Mg}^{2+}>\mathrm{Na}^{+}$tendency is preponderant with increasing soil depth. However, Van Ranst et al. [35] in the soils of Mount Bamboutos and Azinwi Tamfuh et al. [63] in the mountain of Bamenda, found similar trends as that of the soils of Balatchi $\left(\mathrm{Ca}^{2+}>\mathrm{Mg}^{2+}>\mathrm{K}^{+}>\mathrm{Na}^{+}\right)$although variations in cation values are observed. From the analysis of the cationic equilibria of the studied soils, it appears that the average $\mathrm{Mg} / \mathrm{K}$ ratios are higher at Balatchi (4.04 $\pm 1.18)$ than at Bandjoun $(1.07 \pm 0.44)$ and Santchou $(0.55 \pm 0.17)$. On the other hand, for the $\mathrm{Ca} / \mathrm{Mg}$ ratio an inverse trend is observed. The average $\mathrm{Ca} / \mathrm{Mg} / \mathrm{K}$ ratios are 62/11/27, 71/13/16 and 53/32/11 respectively for the Santchou, Bandjoun and Balatchi soils. They show a cation imbalance in favour of $\mathrm{K}$ for the Santchou (0.82/0.59/4.52*) and Bandjoun (0.94/0.73/2.59*) soils and of $\mathrm{Mg}$ for Balatchi soils $\left(0.73 / 1.88^{\star} / 1.77\right)$ compared to the ideal balance of $76 \% \mathrm{Ca}, 18 \%$ $\mathrm{Mg}$ and $6 \% \mathrm{~K}$ for optimal absorption of nutrients by plants [38]. From the analysis of the ratios $(\mathrm{Ca}+\mathrm{Mg}) / \mathrm{K}, \mathrm{Ca} / \mathrm{Mg}$ and $\mathrm{Mg} / \mathrm{K}$, it emerges a potential imbalance and risk of $\mathrm{Ca}$ and $\mathrm{Mg}$ deficiency for the soils of Santchou and Bandjoun and $\mathrm{Ca}$ for the soils of Balatchi [38] [64]. It is thus necessary to restore the balance between the exchangeable cations by adjusting the cation saturation of the soil to $50 \%$ for the topsoil $\left(0-20 \mathrm{~cm}\right.$ depth) (Figure 2). Since $\mathrm{Ca}^{2+}$ is the most deficient exchangeable cation in all soils, it requires an average intake of 9.08 $\mathrm{t} / \mathrm{ha}$ in Santchou, $5.74 \mathrm{t} / \mathrm{ha}$ in Bandjoun and $2.56 \mathrm{t} / \mathrm{ha}$ in Balatchi, respectively.

The mean value of organic carbon was higher in the soils of Balatchi $(6.18 \% \pm$ $0.42 \%)$ compared to those of Santchou $(3.77 \% \pm 0.29 \%)$ and Bandjoun $(3.42 \% \pm$ $0.25 \%)$. The average total nitrogen (NT) content of the studied soils is average in the Santchou soils, low in the Bandjoun soils and very high in the Balatchi soils 


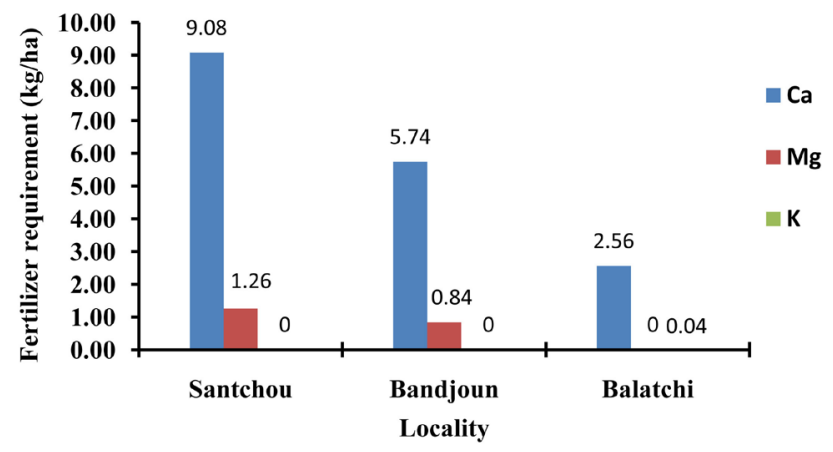

Figure 2. Recommended fertilizer doses to increase the exchangeable cation saturation of the soil to $50 \%$ for the topsoil $(0-20 \mathrm{~cm}$ deep) with a $\mathrm{Ca} / \mathrm{Mg} / \mathrm{K}$ rate of $76 / 18 / 6$ for the different soils $(n=6)$.

[38]. The high NT values could be linked to good mineralization of OM accumulated on the soil surface thanks to nitrous (Nitrosomonas $s p$.) and nitric ( $\mathrm{Ni}$ trobacter $s p$.) bacteria [65] [66]. Also, there is insignificant contribution of ammoniacal fertilizers (urea, ammonium sulphate and ammonium nitrate) to the total nitrogen content of the soil, as these are commonly used by farmers in this agroecological zone to improve their productivity. Also, the levels of total nitrogen and high OM could be associated with the regular application of household waste, which significantly contributes to OM content. However, the quality of this $\mathrm{OM}$ for all the soils studied remains very poor $(\mathrm{C} / \mathrm{N}>20)$ probably due to a very low biological activity. In the hydromorphic soils of Santchou, Nnomo et al. [59] have shown that these high values of $\mathrm{C} / \mathrm{N}$ could be explained by a limited humification process because it stops at the ammonification stage under anaerobic conditions. Thus, from this incomplete reaction, the $\mathrm{NH}_{3}$ could be adsorbed on the complex in the form of $\mathrm{NH}_{4}^{+}$and therefore the potentialities for a good supply of nitrogen in this horizon could be limited to the ammoniacal form instead of the nitrate $\left(\mathrm{NO}_{3}^{-}\right)$as this is the case for the majority of plants.

Average available phosphorus content varies from very high $(69.39 \pm 26.09$ ppm) for Santchou soils to medium $(20.73 \pm 6.65 \mathrm{ppm}$ and $18.32 \pm 3.91 \mathrm{ppm}$, respectively) for Bandjoun and Balatchi soils [38]. A level of available phosphorus of $15 \mathrm{ppm}$ is generally considered to be the critical threshold below which a soil is considered to have low phosphorus content, leading to diseases related to phosphorus deficiency in most plants [67]. The phosphorus values obtained could be explained by the high levels of organic matter in the soils studied.

The average NT/pH ratio varies from $0.003 \pm 0.00$ at Santchou, $0.002 \pm 0.00$ at Bandjoun and from $0.005 \pm 0.00$ at Balatchi. According to Dabin [64], they indicate poor soil fertility in terms of total nitrogen, the average $\mathrm{pH}-\mathrm{H}_{2} \mathrm{O}$ of the soils being slightly acidic (Santchou and Bandjoun) to medium (Balatchi). However, the Fertility Index of all soils is high, showing that the studied soils are in the class of fertile soils [37]. The values obtained are higher than those obtained by Azinwi Tamfuh et al. [68] on the soils of Santa in Northwest Cameroon. 


\subsection{Mycorrhization Frequency of Triumfetta cordifolia Roots}

The frequency of mycorrhization reflects the percentage of roots colonized by arbuscular mycorrhizal fungi. It varies from $42.22 \% \pm 5.28 \%$ in Santchou, $51.67 \% \pm 9.06 \%$ in Bandjoun and $59.44 \% \pm 7.47 \%$ in Balatchi (Table 1). It is moderately variable in Santchou and Balatchi, but very variable in Bandjoun. The variation in the frequency of mycorrhization in different samples of composite soil was previously observed in Cameroon by Temegne et al. [69] on Bambara groundnut (Vigna subterranea) in the Center Region and by Tobolbai et al. [70] and on maize (Zea mays L.) in North Cameroon. The values obtained in this study are not significantly different from one locality to another $(\mathrm{p}=$ 0.15) (Figure 3).

However, they are lower than those reported in India on Triumfetta rhomboidea by Rajkumar et al. [26] where the frequency of mycorrhization was $94 \%$. On the other hand, they are higher than values (30\%) documented by Jayaprakash and Nagarajan [71] for T. Rhomboidea. However, these values are higher $(10<\mathrm{F}(\%)<20)$ than that reported by Tobolbai et al. [70] on maize (Zea mays $L)$ but very close to that $(40.8<\mathrm{F}(\%)<46.9)$ reported by Temegne et al. [69] on Bambara groundnut(Vigna subterranea). For Jansa et al. [72] the low frequency of mycorrhization can be attributed to land use patterns, in particular ploughing, crop rotation and the application of pesticides (mainly fungicides) which negatively affect arbuscular mycorrhizal communities, hence the frequency of mycorrhizae, through substantial decrease in mycorrhizal potential. In the present study, soils are very stressed and subject to intensive agriculture, marked by the use of chemical fertilizers, tillage and the use of pesticides. According to Tester et al. [73], the presence of fungi-toxic compounds at the level of the roots is capable of reducing mycorrhizal colonization. Furthermore, Santchou soils have the highest average phosphorus content $(69.39 \pm 26.09 \mathrm{ppm})$ compared to that of Bandjoun $(20.73 \pm 6.65 \mathrm{ppm})$ and Balatchi $(18.32 \pm 3.91$ $\mathrm{ppm})$. This could justify the lower colonization frequency observed in this area because, for Lopez-Aguillon et Garbaye [74], contributions of 25 and $50 \mathrm{ppm}$ of phosphorus $\left(\mathrm{Ca}\left(\mathrm{H}_{2} \mathrm{PO}_{4}\right)\right)$ significantly reduced the rate of endomycorrhization.

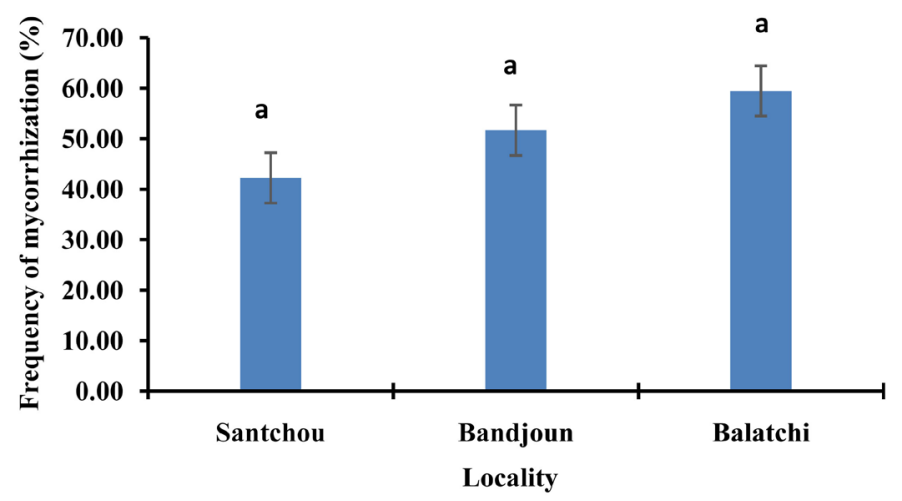

Figure 3. Variation of mycorrhization frequency in Triumfetta cordifolia by locality (n $=6)$. 
However for Temegne et al. (2017), phosphate fertilizer application did not affect the frequency of mycorrhization on Bambara groundnut. According to Temegne et al. [69], simple superphosphate $\left(\mathrm{P}_{2} \mathrm{O}_{5}\right)$ is a slow fertilizer whose solubilization is progressive. This property could explain this result because, unlike other chemical fertilizers (NPK), it behaves like organic fertilizers (natural phosphate (rock), household waste, chicken manure, etc.), which do not reduce the frequency of mycorrhization of AMF [75] [76]. In addition, Duponnois et al. [77] have underlined that mycorrhizal infection of plants varies greatly from one plant to another but also within the same species. Nevertheless, Ngonkeu [78] reported that weak root colonization does not imply low symbiotic efficiency.

\subsection{Mycorrhization Intensity of Triumfetta cordifolia Roots}

The mean mycorrhization rate varies from $2.16 \% \pm 0.51 \%$ in Santchou, $5.81 \% \pm$ $2.06 \%$ in Bandjoun and $3.66 \% \pm 1.11 \%$ in Balatchi. These values are highly variable $(\mathrm{CV}>35 \%)$ in all the localities and are not significantly different $(\mathrm{p}=0.20)$ (Figure 4). Such values are close to those already reported by Tobolbai et al. [70] on maize (Zea mays L.) in Mbéré (3.48\%), Vina (1.41\%), Diamaré (1.4\%) and Mayo Danay (1\%), but lower than that found in Mayo Tshanaga (15.38\%) all in Northern Cameroon. Likewise, these values are lower $(\mathrm{I}=16.1 \%)$ than that reported by Temegne et al. [69] on Bambara groundnut (Vigna subterranea).

The lower rate $(2.16 \% \pm 0.51 \%)$ of the average mycorrhization intensity of $T$. Cordifolia roots obtained in Santchou soils compared to other sites could be explained by the level of available phosphorus (69.39 $\pm 26.09 \mathrm{ppm})$, which is highest in this site compared to Bandjoun $(20.73 \pm 6.65 \mathrm{ppm})$ and Balatchi $(18.32 \pm$ $3.91 \mathrm{ppm}$ ). For Temegne et al. [69], a high level of phosphate fertilizer (200 $\mathrm{kg} / \mathrm{ha} \mathrm{P}_{2} \mathrm{O}_{5}$ ) considerably reduced the intensity of mycorrhization on the Bambara groundnut (Vigna subterranea). For this author, the application of this level of fertilizer could have increased the acidity of the soil. Indeed, the extreme acidity of the soils could be the cause of the low density of spores observed in certain species of arbuscular mycorrhizal fungi (AMF) [79] [80]. Bhadalung et al. [81] pointed out that chemical $P$ fertilization reduces the total number of AMF spores

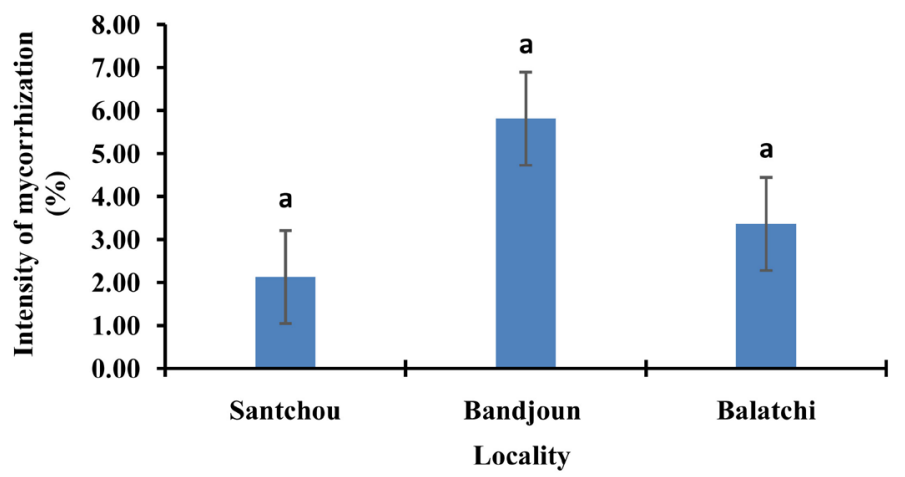

Figure 4. Variation of mycorrhization intensity $( \pm S D)$ in Triumfetta cordifolia by locality $(n=6)$. 
in the long term. A variation in the physical properties of soils, in particular the sandy nature of the soil, could be more favourable to the development of AMF. Bandjoun soils with the highest average sand content $(51.00 \% \pm 2.32 \%)$ have the highest average frequency $(51.67 \% \pm 9.06 \%)$ and intensity $(5.81 \% \pm 2.06 \%)$. These results corroborate those published by Tobolbai et al. [70] which showed that the soils of Mayo Tshanaga (Far North-Cameroon) which had the highest sand content (73.20\%) recorded the highest values of frequency $(20 \%)$ and Intensity of mycorrhization (15.38\%) on maize (Zea mays L.). Similarly, Temegne et al. [69] found on Bambara groundnut (Vigna subterranea) without the addition of phosphate fertilizers, a lower mycorrhization intensity $(21.8 \%)$ in soils with $46 \%$ sand, compared to those with $58 \%$ sand where it was higher $(30.1 \%)$, thus confirming the variation in the intensity of AMF spores with soil physical characteristics.

\subsection{Specific Density of Endomycorrhizal Fungi in the Rhizosphere of Triumfetta cordifolia}

The mean specific density of the spores varies from $18.00 \% \pm 2.85 \%$ in Santchou, $30.33 \% \pm 2.76 \%$ in Bandjoun and $24.17 \% \pm 4.43 \%$ in Balatchi. It is moderately variable in Bandjoun $(\mathrm{CV}=22.33 \%)$ and highly variable in Santchou $(\mathrm{CV}=$ $38.81 \%)$ and Balatchi $(\mathrm{CV}=44.90 \%)$ and no significant difference was observed between the localities $(\mathrm{p}=0.08)$ (Figure 5).

The values obtained are higher than those reported by Voko et al. [81] in Ivory Coast, where the specific density of CMA in the cassava rhizosphere of four different fields was between $8.42 \%$ and $14.69 \%$. However, higher values were revealed by Tobolbai et al. [70] who found a specific density of CMA spores on maize (Zea mays L.) from $91 \%$ in Adamaoua to 591\% in Far North-Cameroon. Likewise, Temegne et al. [69] found a spore density of over $1930 \mathrm{in} 100 \mathrm{~g}$ of soil trapping substrate from Bambara groundnut (Vigna subterranea). The variations in the specific density of the spores could be explained by differences in the physicochemical properties of the different soils studied, in particular phosphorus, $\mathrm{pH}$ and sand. The lowest average specific density was recorded in Santchou $(18.00 \% \pm 2.85 \%)$, which has the highest phosphorus content $(69.39 \pm 26.09$ ppm). Similar results have been documented by Kowalska et al. [82] and

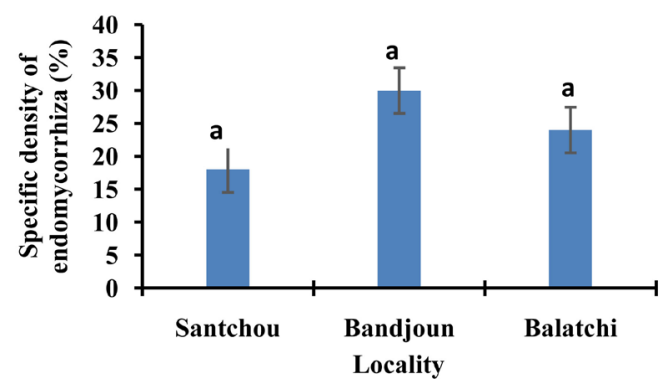

Figure 5. Variation of specific density $( \pm S D)$ of endomycorrhiza in Triumfetta cordifolia by locality $(n=6)$. 
Temegne et al. [69] indicating phosphorus as a factor inhibiting the development of AMF in soil. These observations are also consistent with those reported by Begoude et al. [83] which indicate low specific densities of AMF in plots with high phosphorus content (fertilized with NPK) and high densities in plots with low phosphorus content (plots not fertilized with NPK). Previous research has shown that the availability of high available phosphorus in soils has a strong negative effect on the development of AMF [85]. In addition, P fertilization with high dose and high solubility modifies the abundance, colonization and efficiency of AMF propagules, AMF tending to associate with a low nutrient content milieu, particularly that of P [85] [86]. To this, one could also note the high sand content and the $\mathrm{pH}$ which would favour the development of the spores. The Bandjoun soils with the highest percentage of sand $(51.00 \% \pm 2.32 \%)$ and the highest $\mathrm{pH}-\mathrm{H}_{2} \mathrm{O}(6.92 \pm 0.32)$ recorded the highest spore density $(30.33 \% \pm$ 2.76\%). These results corroborate those obtained by several authors [69] [70]. The high values of spore density obtained in this study compared to that obtained $(8.42 \%-14.69 \%)$ by Voko et al. [81] could be attributed to the undisturbed nature of the ecosystem of the plots of T. cordifolia. Borriello et al. [87] pointed out that intensive tillage in conventional cropping systems negatively affects the AMF community and decreases the number of species, which would go a long way to reduce the sustainability of the system.

\subsection{Correlation between Mycorrhization Parameters and Selected Soil Physicochemical Properties}

Table 3 presents the correlations between selected physicochemical parameters and mycorrhizal status. It appears that the frequency and intensity of mycorrhization recorded significant and positive correlations in all soils. In the hydromorphic soils of Santchou, significant and positive correlations were recorded between sand content and the intensity of colonization $(\mathrm{r}=0.815, \mathrm{p}<0.05)$ on the one hand, and the frequency of colonization and sand $(r=0.875, p<0.05)$ on the other hand. However, the intensity of mycorrhization was negatively correlated with clay $(\mathrm{p}=-0.816, \mathrm{p}<0.05)$. These results indicate that the frequency and intensity of mycorrhization in these soils increase with sand content. Sandy soils are generally more porous, warmer, drier, and less fertile than finer-textured soils, and these conditions have direct and indirect effects on AMF [88]. Good soil aeration is a prerequisite for optimal development of AMF [89].

Soil temperatures of $30^{\circ} \mathrm{C}-35^{\circ} \mathrm{C}$ promote spore germination [90] and the spread of colonizing roots [91]. Moderately high temperatures with an annual average of $23.6^{\circ} \mathrm{C}$ in Santchou associated with high sand content of the soils could be the cause of the increase in the intensity and frequency of colonization with increase in the percentage of sand.

In the Ferrallitic soils of Bandjoun, the specific density of spores is negatively correlated with $\mathrm{pH}-\mathrm{H}_{2} \mathrm{O}(\mathrm{r}=-0.853, \mathrm{p}<0.05)$ and available phosphorus $(\mathrm{r}=$ $-0.812, p<0.05)$. Several studies have shown that the intensity of root colonization by AMF decreases when the level of phosphorus increases in the soil [69] 
Table 3. Correlation between selected soil characteristics $(n=6)$.

\begin{tabular}{|c|c|c|c|c|c|c|c|c|c|}
\hline & $\mathrm{pH}-\mathrm{H}_{2} \mathrm{O}$ & TN (\%) & $\begin{array}{l}\text { Avail P } \\
(\mathrm{ppm})\end{array}$ & Clay (\%) & Silt (\%) & $\begin{array}{c}\text { Sand } \\
(\%)\end{array}$ & $\begin{array}{c}\text { I } \\
(\%)\end{array}$ & $\operatorname{Fr}(\%)$ & Ds (\%) \\
\hline \multicolumn{10}{|c|}{ Santchou } \\
\hline $\mathrm{pH}-\mathrm{H}_{2} \mathrm{O}$ & 1 & & & & & & & & \\
\hline $\mathrm{TN}(\%)$ & 0.655 & 1 & & & & & & & \\
\hline Avail. P (ppm) & $0.813^{*}$ & 0.774 & 1 & & & & & & \\
\hline Clay (\%) & $-0.920^{* *}$ & -0.439 & -0.753 & 1 & & & & & \\
\hline Silt (\%) & 0.448 & 0.550 & $0.867^{*}$ & -0.416 & 1 & & & & \\
\hline Sand (\%) & 0.430 & -0.108 & -0.114 & -0.533 & -0.547 & 1 & & & \\
\hline I (\%) & 0.719 & -0.022 & 0.287 & $-0.816^{*}$ & -0.068 & $0.815^{*}$ & 1 & & \\
\hline $\operatorname{Fr}(\%)$ & 0.663 & 0.153 & 0.261 & -0.768 & -0.180 & $0.875^{*}$ & $0.824^{*}$ & 1 & \\
\hline Ds (\%) & 0.005 & 0.308 & -0.094 & 0.013 & -0.344 & 0.308 & -0.139 & 0.435 & 1 \\
\hline \multicolumn{10}{|c|}{ Bandjoun } \\
\hline $\mathrm{pH}-\mathrm{H}_{2} \mathrm{O}$ & 1 & & & & & & & & \\
\hline $\mathrm{TN}(\%)$ & 0.115 & 1 & & & & & & & \\
\hline Avail. P (ppm) & 0.607 & -0.220 & 1 & & & & & & \\
\hline Clay (\%) & -0.111 & 0.336 & -0.632 & 1 & & & & & \\
\hline Silt (\%) & 0.157 & -0.018 & -0.281 & -0.238 & 1 & & & & \\
\hline Sand (\%) & -0.055 & -0.233 & 0.713 & -0.534 & -0.695 & 1 & & & \\
\hline I (\%) & 0.038 & -0.702 & -0.258 & 0.064 & 0.428 & -0.420 & 1 & & \\
\hline $\operatorname{Fr}(\%)$ & 0.282 & -0.699 & -0.056 & 0.032 & 0.403 & -0.375 & $0.964^{\star *}$ & 1 & \\
\hline Ds (\%) & $-0.853^{*}$ & -0.150 & $-0.812^{*}$ & 0.544 & -0.320 & -0.125 & 0.101 & -0.089 & 1 \\
\hline \multicolumn{10}{|c|}{ Balatchi } \\
\hline $\mathrm{pH}-\mathrm{H}_{2} \mathrm{O}$ & 1 & & & & & & & & \\
\hline TN (\%) & 0.786 & 1 & & & & & & & \\
\hline Avail. P (ppm) & 0.269 & 0.103 & 1 & & & & & & \\
\hline Clay (\%) & 0.402 & 0.234 & 0.103 & 1 & & & & & \\
\hline Silt (\%) & 0.531 & 0.170 & 0.599 & 0.420 & 1 & & & & \\
\hline Sand (\%) & -0.564 & -0.210 & -0.537 & -0.637 & $-0.967^{\star *}$ & 1 & & & \\
\hline I (\%) & -0.638 & $-0.899^{*}$ & 0.076 & 0.340 & 0.001 & -0.096 & 1 & & \\
\hline $\operatorname{Fr}(\%)$ & -0349 & $-0.817^{*}$ & 0.166 & 0.251 & 0.281 & -0.309 & $0.819^{*}$ & 1 & \\
\hline Ds (\%) & 0.388 & $0.841^{*}$ & -0.418 & 0.025 & -0.549 & 0.459 & -0.618 & -0.744 & 1 \\
\hline
\end{tabular}

${ }^{*}$ Correlation is significant at $\mathrm{p}<0.01,{ }^{*}$ Correlation is significant at $\mathrm{p}<0.05$, Avail. P: Available phosphorus.

[70] [82]. Indeed, high content of available phosphorus in the substrate can increase the concentration of this element in plant tissues, which could decrease the release of root exudates, by reducing cell permeability [92]. Low levels of exudates in the rhizosphere would therefore reduce the attraction of germinating 
hyphae to the roots [93]. Likewise, the solid constituents particularly iron and aluminium sesquioxides, which predominate in Ferrallitic soils, adsorb phosphorus and severely limiting its availability could explain the decrease in its content. Under these circumstances, AMF grows more widely inside the root to support the development and functioning of the external hyphae [94].

Total nitrogen in Balatchi soils shows a negative correlation with the frequency of mycorrhization $(\mathrm{r}=-0.899, \mathrm{p}<0.05)$ and the intensity of mycorrhization $(\mathrm{r}=-0.817, \mathrm{p}<0.05)$. However, this correlation is rather positive with the specific density of the spores $(\mathrm{r}=0.841, \mathrm{p}<0.05)$. The work of Cardoso and Kuyper [95] on mycorrhizae and soil fertility in tropical environments has shown that the application of nitrogen in the form of nitrate and ammonium to soil can have a certain inhibitory or stimulating effect for colonization of AMF. It has been proven that the nitrogen present in the form of ammonium has a suppressive effect on the colonization of these mycorrhizae, due to the modification of the $\mathrm{pH}$ of the rhizosphere [95]. For Valentine et al. [96], the diversity of inorganic nitrogen forms existing in the soil influences the percentage of colonization, the length of roots and the presence of types of colonizing structures such as arbuscules. These assumptions could explain the results obtained in this area characterized by the intensive use of inorganic nitrogen fertilizers for agricultural production associated with the lowest average $\mathrm{pH}(5.83 \pm 0.16)$ obtained in the soils of this study. However, in these soils, the density of spores and the frequency of colonization show a significant and negative correlation. These results disagree with those of Rajkumar et al. [26], who found that increased spore density did not correlate with increased rates of mycorrhizal colonization. For some authors [90] [97], arbuscular mycorrhizal fungal sporulation depends on a wide range of fungal and environmental factors of the host, and their germination potential varies at different periods of the year.

\section{Conclusion}

The results of physicochemical analysis of the soils of three localities in the Cameroon Western Highlands showed variation from one site to another and play a role in the mineral nutrition of $T$. cordifolia. On average the soils had a loamy texture, favorable bulk density, and good to very good porosity. These soils were slightly acidic (Santchou and Bandjoun) and moderately acidic (Balatchi). The exchangeable cations were moderate (Santchou and Bandjoun) to high (Balatchi). The total nitrogen content was medium in Santchou, low in Bandjoun and very high in Balatchi. Although the organic matter status is satisfactory, the biological activity is reduced due to its very poor quality. Phosphorus contents ranged from medium (Bandjoun and Balatchi) to very high (Santchou). The regular supply of organic matter, the undisturbed nature of the T. cordifolia ecosystem, anthropogenic fertilization and the slightly acidic nature of soils seem favourable to the immobilization of phosphorus. The CEC is moderate for all the studied soils. These characteristics favour root development and 
could promote the cultivation of Malvaceae. However, adequate soil fertility management options are required in order to improve the fertility status of the soils. Such measures would involve adjusting the $\mathrm{pH}$ values close to neutral, promoting biological activity through a supply of good quality OM. The link between soil physicochemical properties and the colonization of AMF in $T$. cordifolia is an important factor to be considered in promoting the establishment of mycorrhizal symbiosis for profitable and sustainable cultivation of $T$. cordifolia.

\section{Funding}

This work did not receive any specific grant from funding agencies in the public, commercial, or not-for-profit sectors.

\section{Conflicts of Interest}

The authors declare that they have no conflict of interest.

\section{References}

[1] FAO (2020) L'insécurité Alimentaire: La faim au quotidien et la crainte permanente de la famine. Organisation des Nations Unies pour l'alimentation et l'agriculture, Rome, 1-4.

[2] Schippers, R.R. (2000) African Indigenous Vegetables: An Overview of the Cultivated Species Chatham. Natural Resources Institute/ACP-EU Technical Centre for Agricultural and Rural Cooperation.

[3] Abukutsa-Onyango, M.O. (2010) African Indigenous Vegetables in Kenya: Strategic Repositioning in the Horticultural Sector. https://www.researchgate.net/publication/235323508

[4] Natesh, H., Abbey, L. and Asiedu, S. (2017) An Overview of Nutritional and Anti Nutritional Factors in Green Leafy Vegetables. Horticulture International Journal, 1, 58-65. https://doi.org/10.15406/hij.2017.01.00011

[5] Opiyo, A.M., Mungai, N.W., Nakhone, L.W. and Lagat, J.K. (2015) Production, Status and Impact of Traditional Leafy Vegetables in Household Food Security: A Case Study of Bondo District-Siaya County-Kenya. ARPN Journal of Agricultural and Biological Science, 10, 330-338.

[6] Fokou, E., Ponka, R., Tchinda, D.P.H., Domguia, K.H.B., Tchouba, L.B., Achu, M.B. and Fotso, M. (2009) Methods of Preparation and Nutritive Value of Some Dishes Consumed in the West Region of Cameroon. Pakistan Journal of Nutrition, 8, 1190-1195. https://doi.org/10.3923/pjn.2009.1190.1195

[7] Tchoukoua, A., Sandjo, L.P., Keumedjio, F., Ngadjui, B.T. and Kirsch, G. (2013) Triumfettamide B, a New Ceramide from the Twigs of Triumfetta Rhomboidea. Chemistry of Natural Compounds, 49, 811-814. https://doi.org/10.1007/s10600-013-0753-3

[8] Vivien, J. and Faure, J.J. (1985) Arbres Des Forêts Denses d'Afrique Centrale: Espèce Du Cameroun. Editeur: Ministère Des Relations Extérieures, Coopération et Développement, 323-325.

[9] Schippers, R.R. (2004) Légumes Africains Indigènes. Présentantion Des Espèces Cul-tivées. Margraf Publishers-CTA. 
[10] Saidou, C. (2012) Propriétés Physico-Chimiques et Fonctionnelles Des Gommes Hy-drocolloïdes Des Écorces de Triumfetta cordifolia et Bridelia Thermifolia. Université de Grenoble, Université de Ngaoundéré.

[11] Jiofack, T. (2012) Triumfetta cordifolia A. Rich. In: Brink, M. and Achigan-Dako, E.G., Eds., Ressources Végétales de 1 Afrique Tropicale 16. Plantes à Fibres [Traduction de: Plant Resources of Tropical Africa 16. Fibres. 2012], Fondation PROTA, Wageningen, Pays-Bas/CTA, Wageningen, Pays-Bas, 493-496.

[12] Ajoko, I.T., Amos-Tautua, B.M.W. and Songea, S.P. (2020) Ethnomedicinal and Economical Profile of Triumfetta cordifolia: A Mini-Review. Journal of Medicinal Plants Studies, 8, 208-2012.

[13] Nwafor, P.A., Ekpo, B.A.J., Ajibesin, K.A. and Bala, D.N. (2011) Evaluation of Anti-Diarrhoeal and Anti-Ulcer Properties of Fractions of Triumfetta cordifolia A. Rich (Tiliaceae) Fruit in Rats. African Journal of Biomedicine Reserve, 14, 49-55.

[14] Odewo, S.A. and Adeyemo, A. (2018) Ethnobotany of Forest Plants Used in Traditional Treatment of Benorrhoea in Orile-Owu Osun State, Nigeria. Journal of Medicinal Plants Studies, 6, 25-29.

[15] Orodeh, V., Aderibigbe, A.O. and Benneth, B. (2019) Evaluation of the Psychopharmacology Properties and Neural Mechanisms of Action of the Ethanol Extract of Leaves of Triumfetta cordifolia in Mice. Journal of Pharmacy and Bioresources, 16, 76-89. https://doi.org/10.4314/jpb.v16i1.9

[16] Borokini, I.T. and Omotayo, F.O. (2012) Phytochemical and Ethnobotanical Study of Some Selected Medicinal Plants from Nigeria. Journal of Medicinal Plants Reserve, 6, 1106-1118. https://doi.org/10.5897/JMPR09.430

[17] Fongnzossie, E.F., Tize, Z., FogangNde, P.J., NyangonoBiyegue, C.F., BoueletNtsama, I.S., Dibong, S.D. and Nkongmeneck, B.A. (2017) Ethnobotany and Pharmacognostic Perspective of Plant Species Used as Traditional Cosmetics and Cosmeceuticals among the Gbaya Ethinc Group in Eastern Cameroon. South African Journal of Botany, 112, 29-39. https://doi.org/10.1016/j.sajb.2017.05.013

[18] Ngondi, J.L., Etame, S.L., Oben, J. and Makamto, S.C. (2006) Effect of Triumphetta Cordifolia on Body Weight and Blood Lipids in Normolipidemic Guinea Pigs. Drug Development Research, 66, 200-203. https://doi.org/10.1002/ddr.20039

[19] Sandjo, L.P. and Kuete, V. (2013) 15 Ceramides, Cerebrosides, and Related Long Chains Containing Derivatives from the Medicinal Plants of Africa. In: Kuete, V., Ed., Medicinal Plant Research in Africa, Elsevier, Oxford, 607-620. https://doi.org/10.1016/B978-0-12-405927-6.00015-1

[20] Sandjo, L.P., Hannewald, P., Yemloul, M., Kirsch, G. and Ngadjui, T. (2008) Triumfettamide and Triumphettoside Ic, Two Ceramides and Other Secondary Metabolites from Stems of Wild Triumfetta cordifolia A. Rich. (Tiliaceae). Helvetica Chimica Acta, 91, 1326-1335. https://doi.org/10.1002/hlca.200890144

[21] Sandjo, L.P., Tchoukoua, A., Nga, N.H., Yemloul, M., Perspicace, E., Keumedjio, F., Couty, F., Kirsch, G. and Tchaleu, N.B. (2010) New Nortriterpenoid and Ceramides from Stems and Leaves of Cultivated Triumfetta cordifolia A Rich (Tiliaceae). Journal of American Oil Chemistry Society, 87, 1167-1177. https://doi.org/10.1007/s11746-010-1584-Z

[22] Louis, M., Huber, T., Benton, R., Sakmar, T.P. and Vosshall, L.B. (2008) Bilateral Olfactory Sensory Input Enhances Chemotaxis Behavior. Natural Neuroscience, 11, 187-199. https://doi.org/10.1038/nn2031

[23] Bationo, A., Mugbogho, S. and Mokwunye, A. (1986) Agronomic Evaluation of Phosphate Fertilizers in Tropical Africa. In: Mokwunye, A.U. and Vleck, P.L.G., 
Eds., Management of Nitrogen and Phosphorus Fertilizers in Sub-Saharan Africa, Martinus Nijhoff, Dordrecht, 283-318. https://doi.org/10.1007/978-94-009-4398-8_10

[24] Onguene, N.A., Ngonkeu, E.L.M. and Kuyper, T.W. (2010) Growth Response of Pterocarpus soyauxii and Lophira alata Seedling to Host Soil Mycorrhizal Inocula in Relation to Land Use Types. Cameroon Journal of Experimental Biology, 6, 63-73. https://doi.org/10.4314/cajeb.v6i2.68523

[25] Taffouo, V.D., Ngwene, B., Akoa, A. and Franken, P. (2014) Influence of Phosphorus Application and Arbuscular Mycorrhizal Inoculation on Growth, Foliar Nitrogen Mobilization, and Phosphorus Partitioning in Cowpea Plants. Mycorrhiza, 24, 361-368. https://doi.org/10.1007/s00572-013-0544-5

[26] Rajkumar, H.G., Seema, H.S. and Sunil Kumar, C.P. (2012) Diversity of Arbuscular Mycorrhizal Fungi Associated with Some Medicinal Plants in Western Ghats of Karnataka Region, India. World Journal of Science and Technology, 2, 13-20.

[27] Vishal, R.K. and Ramjan, M.M. (2013) Assessment of Some Coastal Psammophytes for AM Fungal Association. Annals of Biological Research, 4, 7-11.

[28] Saranya Babu, J.C.M. and Nagarajan, N. (2017) Studies on Mycorrhizal Biodiversity in Medicinal Plant Species of Pookode Lake Area, Wayanad, India. Annals of Plant Sciences, 6, 1838-1844. https://doi.org/10.21746/aps.2017.6.12.6

[29] Brundrett, M., Ashwath, N., Jasper, D., Abbott, L., Bougher, N., Brennan, K. and Malajczuk, N. (1995) Mycorrhizal Associations in the Alligator Rivers Region Final Report Part II Experimental Results. No. 110. https://www.researchgate.net/publication/305708967

[30] Bourgeon, G. (1979) Etude Morphopédologique de Détail de La Plaine Des Mbo. Rapport de Recherche, Ministère de l'agriculture, République Unie Du Cameroun IRAT.

[31] Takala, H.B. (2017) Caractérisation Geotechnique et Évaluation En Construction Routière Des Latérites de Batoufam, Ouest Cameroun. 16.

[32] Kengni, L., Tekoudjou, H., Tematio, P., Pamo Tedonkeng, E., Tankou, C.M., Lucas, Y. and Probst, J.L. (2008) Rainfall Variability along the Southern Flank of the Bambouto Mountain (West-Cameroon). Journal of the Cameroon Academy of Sciences, 8, 45-52.

[33] Olivry, J.C. (1976) Régimes Hydrologiques En Pays Bamiléké (Cameroun). Cahier Orstom, 71.

[34] Sadio, S. (1987) Les Sols Rouges: Etendue, Caractéristiques Physico-Chimiques, Classification et Évaluation Pour La Mise En Valeur Agricole. Institut français de Recherches Scientifiques pour le Développement en Coopération (ORSTOM), Yaoundé, 36.

[35] Van Ranst, E., Doube, M., Mees, F., Dumon, M., Ye, L. and Delvaux, B. (2019) Andosolization of Ferrallitic Soils in the Bambouto Mountains, West Cameroon. Geoderma, 340, 81-93. https://doi.org/10.1016/j.geoderma.2018.12.024

[36] Pauwels, J.M., Van Ranst, E., Verloo, M. and Mvondo Ze, A. (1992) Manuel de La-boratoire de Pédologie-Méthode d'analyse Des Sols et de Plantes; Équipements et Gestion Des Stocks de Verrerie et de Produits Chimiques. Public. A.G.C.D., Bruxelles.

[37] Beernaert, F. and Bitondo, D. (1993) Land Evaluation Manual. Dschang University Center, Dschang.

[38] Beernaert, F. and Bitondo, D. (1992) Simple and Practical Methods to Evaluate 
Analytical Data of Soil Profiles. CUDs Dschang Soil Sciences Department, Belgium Cooperation, Dschang.

[39] Phillips, J.M. and Hayman, D.S. (1970) Improved Procedures for Clearing Roots and Staining Parasitic and Vesicular-Arbuscular Mycorrhizal Fungi for Rapid Assessment of Infection. Transactions of the British Mycological Society, 55, 158-161. https://doi.org/10.1016/S0007-1536(70)80110-3

[40] Vierheilig, H., Coughlan, A.P., Wyss, U. and Piche, Y. (1998) Ink and Vinegar, a Simple Staining Technique for Arbuscular-Mycorrhizal Fungi. Applied and Environmental Microbiology, 64, 5004-5007.

https://doi.org/10.1128/AEM.64.12.5004-5007.1998

[41] Aubin, M.P. (2016) Impact de l'utilisation Des Mycorhizes à Arbuscules Sur l'accès Aux Éléments Nutritifs Du Chanvre et Sur La Rentabilité de La Production. Programme: Appui Au Développement de l'agriculture et de l'agroalimentaire En Région VOLET: Appui Au Développement Économique de l'agriculture et de l'agroalimentaire.

[42] Trouvelot, A., Fardeau, J.C., Plenchette, C., Gianinazzi, S. and Gianinazzi-Pearson, V. (1986) Nutritional Balance and Symbiotic Expression in Mycorrhizal Wheat. Physiologie Vegetale, 24, 300.

[43] Oehl, F., Sieverding, E., Ineichen, K., Mäder, P., Boller, T. and Wiemken, A. (2003) Impact of Land Use Intensity on the Species Diversity of Arbuscular Mycorrhizal Fungi in Agroecosystems of Central Europe. Applied and Environmental Microbiology, 69, 2816-2824. https://doi.org/10.1128/AEM.69.5.2816-2824.2003

[44] Gerdemann, J. and Nicolson, T. (1963) Spores of Mycorrhizal Endogone Species Extracted from Soil by Wet Sieving and Decanting. Transactions of the British Mycological Society, 46, 235-244. https://doi.org/10.1016/S0007-1536(63)80079-0

[45] Sghir, F., Chliyeh, M., Kachkouck, W., Khouader, M., Touhami, A., Benkirane, R. and Douira, A. (2013) Mycorrhizal Status of Olea europaea Spp. Oleaster in Morocco. Journal of Applied Biosciences, 61, 4478-4489. https://doi.org/10.4314/jab.v61i0.85596

[46] Giday, O., Gibrekidan, H. and Berhe, T. (2015) Soil Fertility Characterization in Vertisols of Southern Tigray, Ethiopia. Advances in Plants \& Agriculture Research, 2, 7-13. https://doi.org/10.15406/apar.2015.02.00034

[47] Charrier, A., Jacquot, M., Hamon, S. and Nicolas, D. (1997) L'amélioration Des Plantes Tropicales. CIRAD et ORSTOM, Toulouse.

[48] Brady, N.C. and Weil, R.R. (2002) The Nature and Properties of Soils. 13th Edition, Pearson Prentice Hall Inc. Pte. Ltd. Indian Branch, Delhi.

[49] Yerima, K.P.B. and Van Ranst, E. (2005) Major Soil Classification Systems Used in the Tropics, Soils of Cameroon. Trafford Publishing, Victoria.

[50] Aubertin, G.M. and Kardos, L.T. (1965) Root Growth through Porous Media under Controlled Conditions II. Effect of Aeration Levels and Rigidity. Soil Science Society of America Journal, 29, 363-365. https://doi.org/10.2136/sssaj1965.03615995002900040007x

[51] Donahue, R., Miller, R.W. and Shickluna, J.C. (1983) Soils: An Introduction to Soils and Plant Growth. 5th Edition, Prentice-Hall, Englewood Cliffs. http://lib.ugent.be/catalog/rug01:000099533

[52] Dosso, M. and Ruellan, A. (2002) Le Sol et La Production Végétale. In Mémento de l'agronome, Cirad, Gret. Ministère français des affaires étrangères, Paris Jouves.

[53] Flint, L.E. and Flint, A.L. (2002) Porosity. In: Methods of Soil Analysis, John Wiley 
\& Sons Ltd., Hoboken, 241-254. https://doi.org/10.2136/sssabookser5.4.c11

[54] Heller, R., Esnault, R. and Lance, C. (1993) Physiologie Végétale 1. Nutrition. 5e Edition de l'Abrégé. Masson, Paris.

[55] Borah, K.K., Bhuyan, B. and Sarma, H.P. (2010) Lead, Arsenic, Fluoride, and Iron Contamination of Drinking Water in the Tea Garden Belt of Darrang District, Assam, India. Environmental Monitoring and Assessment, 169, 347-352. https://doi.org/10.1007/s10661-009-1176-2

[56] Adéchina, O., Yapi, A. and Yao-Kouamé, A. (2016) Inventory of Soil Invertebrate Macrofauna, Bioindicator of Soil Quality, along a Toposequence in an AgroEcological Area of Ahoue (Southern Côte d'Ivoire). International Journal of Science and Research, 5, 455-463. https://doi.org/10.21275/v5i7.ART2016172

[57] Fardeau, J.C. (2015) Des Indicateurs de La Fertilité Des Sols. Étude et Gestion Des Sols. 77-100.

[58] Bongers, F., Charles-Dominique, P., Forget, P. and Théry, P.M. (2001) Nouragues-Dynamics and Plant-Animal Interactions in a Neotropical Rainforest. Springer Science \& Business Media, Berlin. https://doi.org/10.1007/978-94-015-9821-7

[59] Nnomo, D.R., Yerima, K.P.B., Nguetsop, V.F., Onana, A.A. and Tiokeng, B. (2019) Physicochemical Characterisation of Hydromorphic Soils under Fleroya Stipulosa (Rubiaceae), a Vulnerable and Highly Medicinal Plant in Cameroon. Scholars Academic Journal of Biosciences, 7, 205-2019.

[60] Kambiré, S. (1994) Systèmes de Culture Paysan et Productivité Des Sols Ferrugineux Lessivés Du Plateau Central (Burkina Faso): Effets Des Restitutions Organiques. Da-kar, Sénégal.

[61] Kawano, K. (2000) The Role of Improved Cassava Cultivars in Generating Income for Better Farm Management. Proceedings of the 6 th Regional Workshop, Ho Chi Minh City, 21-25 February 2000, 5-15.

[62] Boyer, J. (1978) Le Calcium et Le Magnésium Dans Les Sols Des Régions Tropicales Humides et Sub-Humides. ORSTOM, Paris.

[63] Azinwi Tamfuh, P., Tsozué, D., Tita, M.A., Boukong, A., Ngnipa, T.H., Ntangmo, T.H. and Mvondo Ze, A.D. (2017) Effect of Topographic Position and Seasons on the Micro-Nutrient Levels in Soils and Grown Huckleberry (Solanum Scabrum) in Bafut (North-West Cameroon). World Journal of Agricultural Research, 5, 73-87. https://doi.org/10.12691/wjar-5-2-3

[64] Dabin, M.B. (1963) Etude Pour La Reconversion Des Cultures de Caféier Dans La République d Côte d'Ivoire. BDPA/ORSTOM, Paris.

[65] Yerima, K.P.B. and Van Ranst, E. (2005) Introduction to Soil Science: Soils of the Tropics. Trafford Publishing, Victoria.

[66] Watanabe, Y., Kikuno, H., Asiedu, R., Masunaga, T. and Wakatsuki, T. (2015) Comparison of Physicochemical Properties of Soils under Contrasting Land Use Systems in Southwestern Nigeria. Japan Agricultural Research Quarterly, 49, 319-331. https://doi.org/10.6090/jarq.49.319

[67] London, J.R. (1991) Booker Tropical Soil Manual. A Handbook for Soil Survey and Agricultural Land Evaluation in the Tropics and Subtropics. Longman Scientific \& Technical Publishers, New York.

[68] Azinwi Tamfuh, T., Chotangui, A.H., Kate, V.Y., Achantap, R.A., Magha, A.M., Moundjeu, D.E., Tabi, F.O. and Bitom, D. (2020) Land Characteristics and Agricultural Suitability Status along a Toposequence in Santa, Bamenda Highlands, Ca- 
meroon. Journal of Atmospheric \& Earth Science, 4, 22.

https://doi.org/10.24966/AES-8780/100022

[69] Temegne, N.C., Wakem, G.A.L., Taffouo, V.D., Mbogne, T.J., Onguene, N.A. Youmbi, E. and Ntsomboh-Ntsefong, G. (2017) Effect of Phosphorus Fertilization on Arbuscular Mycorrhizal Fungi in the Bambara Groundnut Rhizosphere. African Journal of Microbiology Research, 11, 1399-1410.

https://doi.org/10.5897/AJMR2017.8680

[70] Tobolbai, R., Adamou, S. and Ngakou, A. (2018) Morphological and Structural Diversities of Indigenous Endomycorrhiza Communities Associated to Maize [Zea mays (L.)] in Northern Cameroonian Soils. Journal of Animal \& Plant Sciences, 38, 6057-6073.

[71] Jayaprakash, C.M. and Nagarajan, N. (2017) Studies on Mycorrhizal Biodiversity in Medicinal Plant Species of Pookode Lake Area, Wayanad, India. Annual of Plant Science, 6, 1835-1844. https://doi.org/10.21746/aps.2017.6.12.6

[72] Jansa, J., Erb, A. and Oberholzer, H. (2014) Soil and Geography Are More Important Determinants of Indigenous Arbuscular Mycorrhizal Communities than Management Practices in Swiss Agricultural Soils. Molecular Ecology, 28, 2118-2135. https://doi.org/10.1111/mec.12706

[73] Tester, M., Smith, S.E. and Smith, F.A. (1987) The Phenomenon of Non-Mycorrhizal Plant. Canadian Journal of Botany, 65, 419-431. https://doi.org/10.1139/b87-051

[74] Lopez-Aguillon, R. and Garbaye, J. (1988) Some Aspect of a Double Symbiosis with Ectomycorrhizal and VAM Fungi. Sous Presse, Praha.

[75] Leyval, C., Steinberg, C., Norini, M.P., Beguiristain, T., Edel-Hermann, V., Gautheron, N., Lebeau, T. and Houot, S. (2009) Impact d'amendements Organiques Sur La Structure Des Communautés Microbiennes Des Sols: Choix Des Méthodes, Validation et Résultats. EGS, 299-312.

[76] Mbogne, T.J., Temegne, N.C., Hougnandan, P., Youmbi, E., Tonfack, L.B. and Ntsomboh-Ntsefong, G. (2015) Biodiversity of Arbuscular Mycorrhizal Fungi of Pumpkins (Cucurbita Spp.) under the Influence of Fertilizers in Ferralitic Soils of Cameroon and Benin. Journal of Applied Biology \& Biotechnology, 3, 1-10.

[77] Duponnois, R., Plenchette, C., Thioulouse, J. and Cadet, P. (2001) The Mycorrhizal Soil Infectivity and Arbuscular Mycorrhizal Fungal Spore Communities in Soils of Different Aged Fallows in Senegal. Applied Soil Ecology, 17, 239-251.

https://doi.org/10.1016/S0929-1393(01)00132-9

[78] Ngonkeu, M.E.L. (2013) Biodiversité et Potentiel Des Mycorhizes à Arbuscules de Vertaines Zones Agro-Écologiques Du Cameroun. Thèse de Doctorat 3ème Cycle. Université de Yaoundé I Cameroun. In: Duponnois, R., Hafidi, M., Ndoye, I., Ramanankierana, H. and Bâ, A., Eds., Des Champignons Symbiotiques Contre La Désertification, Ecosystème Méditérranéens, Tropicaux et Insulaires, IRD editions, Marseille, 511.

[79] Bhadalung, N.N., Suwanarit, A., Nopamornbodi, O., Thamchaipenet, A. and Rung-chuang, J. (2005) Effects of Long-Term Npfertilization on Abundance and Diversity of Arbuscular Mycorrhizal Fungi under a Maize Cropping System. Plant Soil, 270, 371-382. https://doi.org/10.1007/s11104-004-1829-4

[80] Bivoko, D.R.R., Ahonzo-Niamke, S.L. and Zeze, A. (2013) Impact Des Propriétés Physicochimiques Des Sols de Culture Du Manioc Sur l'abondance et La Diversité Des Communautés de Champignons Mycorhiziens à Arbuscules Dans La Zone Agroécologique d'Azaguie, Sud-Est de La Côte d'ivoire. Agronomie Africaine, 25, 251-264. 
[81] Voko, D.-RR.B., Nandjui, J., Jean-marc drolet Sery, J.-M., Fotso, B., Amoa, J.A., marie stephanie aka Kouadio, M.-S., Coulibaly, S., Niamke, S. and Zeze, A. (2013) Abundance and Diversity of Arbuscular Mycorrhizal Fungal (AMF) Communities Associated with Cassava (Manihot Esculenta Crantz) Rhizosphere in Abengourou, East Côte d'Ivoire. Journal of Ecology and the Natural Environment, 5, 306-370. https://doi.org/10.5897/JENE2013.0407

[82] Kowalska, I., Konieczny, A., Gąstol, M., Sady, W. and Hanus-Fajerska, E. (2015) Effect of Mycorrhiza and Phosphorus Content in Nutrient Solution on the Yield and Nutritional Status of Tomato Plants Grown on Rockwool or Coconut Coir. Agricultural and Food Science, 24, 39-51. https://doi.org/10.23986/afsci.47204

[83] Begoude, D., Sarr, A.P.S., Mpon, T.L.Y., Owona, D.A., Kapeua, M. and Araki, N. (2016) Composition of Arbuscular Mycorrhizal Fungi Associated with Cassava (Manihot Esculenta Crantz) Cultivars as Influenced by Chemical Fertilization and Tillage in Cameroon. Journal of Applied Biosciences, 98, 9270-9283. https://doi.org/10.4314/jab.v98i1.4

[84] Beenhouwer, M.D., Geel, M.V., Ceulemans, T., Muleta, D., Lievens, B. and Honnay, O. (2015) Changing Soil Charactheristics Alter the Arbuscular Mychorrizal Fungi Communities of Arabica Coffee (Coffea arabica) in Ethiopia across a Management Intensity Gradient. Journal of Soil Biology and Biochemistry, 91, 133-139. https://doi.org/10.1016/j.soilbio.2015.08.037

[85] Heijden, M.G.A., Engel, R.S., Riedl, R., Siegrist, S., Neudecker, A., Boller, T., Wiemken, A. and Sande, I. (2006) The Mycorrhizal Contribution to Plant Productivity, Plant Nutrition and Soil Structure in Experimental Grassland. International Journal of New Phytologist, 172, 739-752. https://doi.org/10.1111/j.1469-8137.2006.01862.x

[86] Smith, S.E. and Read, D.J. (2008) Mycorrhizal Symbiosis. Third Edition, Academic Press, San Diego.

[87] Borriello, R., Lumini, E., Girlanda, M., Bonfante, P. and Bianciotto, V. (2012) Effects of Different Management Practices on Arbuscular Mycorrhizal Fungal Diversity in Maize Fields by a Molecular Approach. Biology and Fertility of Soils, 48, 911-922. https://doi.org/10.1007/s00374-012-0683-4

[88] Sylvia, D.M. and Williams, S.E. (1992) Vesicular-Arbuscular Mycorrhizae and Environmental Stress. In: Bethlenfalvay, G.J. and Linderman, R.G., Eds., Mycorrhizae in Sustainable Agriculture, Special Publication 54, ASA, Madison, 101-124. https://doi.org/10.2134/asaspecpub54.c5

[89] Saif, S.R. (1981) The Influence of Soil Aeration on the Efficiency of Vesicular-Arbuscular Mycorrhiza. I. Effect of Soil Oxygen on the Growth and Mineral Uptake of Chromolaena odorata L. Inoculated with Glomus Macrocarpus. New Phytologist, 88, 649-659. https://doi.org/10.1111/j.1469-8137.1981.tb01741.x

[90] Tommerup, I.C. (1983) Spore Dormancy in Vesicular Arbuscular Mycorrhizal Fungi. Transactions of British Mycological Society, 81, 37-38. https://doi.org/10.1016/S0007-1536(83)80201-0

[91] Bowen, G.D. (1987) The Biology and Physiology of Infection and Its Development. In: Safir, G.R., Ed., Ecophysiology of Mycorrhizal Plants, CRC Press, Boca Raton, 27-70.

[92] Koske, R.E. and Gemma, J.N. (1995) Fungal Reactions to Plants Prior to Mycorrhizal Formation. In: Allen, M.F., Ed., Mycorhizal Functioning. An Integrative Plant Fungal Processes, Chapman and Hall, New York, 3-36.

[93] Tawaraya, K., Hashimoto, K. and Wagatsuma, T. (1998) Effect of Root Exudate 
Fractions from P-Deficient and P-Sufficient Onion Plants on Root Colonization by the Arbuscular Mycorrhizal Fungus Gigaspora Margarita. Mycorrhiza, 8, 67-70. https://doi.org/10.1007/s005720050214

[94] Sanders, F.E., Tinker, P.B., Black, R.L.B. and Palmerley, S.M. (1977) The Development of Endomycorrhizal Root Systems. I. Spread of Infection and GrowthPromoting Effects with Four Species of Vesicular-Arbuscular Endophyte. New Phytologist, 78, 553-559. https://doi.org/10.1111/j.1469-8137.1977.tb04829.x

[95] Cardoso, I.M. and Kuyper, T.W. (2006) Mycorrhizas and Tropical Soil Fertility. Agriculture, Ecosystem, Environment, 116, 72-84. https://doi.org/10.1016/j.agee.2006.03.011

[96] Valentine, A.J., Osborne, B.A. and Mitchell, D.T. (2002) Form of Inorganic Nitrogen Influences Mycorrhizal Colonization and Photosynthesis of Cucumber. Sciencia Horticulturae, 92, 229-239. https://doi.org/10.1016/S0304-4238(01)00302-8

[97] Koske, R.E., Gemma, J.N. and Flynn, T. (1992) Mycorrhizae in Hawaiian Angiosperms: A Survey with Implications for the Origin of Native Flora. American Journal of Botanic, 79, 853-862. https://doi.org/10.1002/j.1537-2197.1992.tb13666.x 